\title{
Jawanesia and Javenglish Phenomenon in Tweet on Twitter Social Media
}

\author{
Chafit Ulya ${ }^{1}$, Muhammad Rohmadi ${ }^{2}$, Ulfa Rizqi Putri ${ }^{3}$, Keken Wulansari ${ }^{4}$, Memet \\ Sudaryanto ${ }^{5}$ \\ \{chafit@staff.uns.ac.id ${ }^{1}$, mamad_r76@staff.uns.ac.id², ulfakiky@student.uns.ac.id ${ }^{3}$, \\ kekenw@student.uns.ac.id ${ }^{4}$, memetsudaryanto@gmail.com ${ }^{5}$ \} \\ Universitas Sebelas Maret, Indonesia ${ }^{1234}$ \\ Universitas Jenderal Soedirman, Indonesia ${ }^{5}$
}

\begin{abstract}
The era of social media has contributed a lot in influencing our language attitudes and behavior, especially among teenagers. Through social media, many unique linguistic phenomena have emerged. One of them is the phenomenon of mixing Javanese and English (Javenglish) in an unusual manner. This research discusses Javanese-Indonesian code switching on tweeter's tweets. This study uses a qualitative descriptive method with a source of data from tweets on Twitter social media. The results of this study indicate that the Javenglish phenomenon occurs in the form of interference, code mixing, and code switching. This Javenglish phenomenon shows language creativity among teenagers that deserves an appreciation. In addition, the results of the analysis show that the phenomenon of Jawanesia (Javanese-Indonesian code switching) in tweets on Twitter includes three patterns, namely inter-sentential code switching, intra-sentential code switching, and symbolic code switching or emblematic switching. The form of code switching in a twitter tweet can be in the form of words, phrases or clauses. The use of Javanese-Indonesia code switching has several functions, namely refining, coarsening, upgrading, and transferring. The phenomenon of Jawanesia in tweets on Twitter is a form of language creativity, which does exist, especially for Indonesians who are bilingual.
\end{abstract}

Keywords: Social Media, Twitter, Switch Code, Jawa-Indonesia

\section{Introduction}

Language is a mean of communication that becomes main part of the society. Through language, humans can communicate with each other and exchange information. Indonesia is a country with diversity of languages from Sabang to Merauke. This causes the Indonesian people to have various regional languages. To unite the diversity of regional languages, Indonesia has a national language, namely Indonesian. However, in the practice, there are many phenomena of mixing regional languages and Indonesian languages. Language is not only a means of communicating an object, but also building and maintaining relationships with other people [1]. Therefore, linguistic learning has a focus on language variation and seeing its context in the social realm [2]. In linguistics, this branch is studied by sociolinguistics. The use of standard Indonesian is an obstacle because there are still various language errors occur in the society [3]. Language errors are caused by language symptoms such as interference, integration, code mixing, code switching and slang which is often 
unwittingly used in official communications. This causes the language used to be bad. Deviations from linguistic rules by learners can be called language errors [4]. Not only that, Indonesia is a country that has many regional languages. The general condition that occurs in Indonesia is that in a region, they use more than one language. Therefore, there are lots of language errors, code mixing, and code switching.

The errors occur systematically and repeatedly, meanwhile mistakes are actions that can be corrected because they occur due to psychological or lack of attention to the use of correct language [5]. In addition, language errors can also occur because of language contact. A feature of error is something the speaker accidentally utters and can easily be corrected by the speaker. There are three categories of errors, namely interlingual errors, developmental errors, intra-lingual errors. Interlingual errors are errors that occur because of differences between the mother tongue and the target language. These errors depend on the native language system, but represent general errors in foreign language learning.

One of the subjects in sociolinguistics is the phenomenon of code switching. Code switching is an event of using two or more languages at one time of communication [6]. Code switching usually occurs in a bilingual social environment, which is a linguistic community that uses two or more languages as a means of interaction [7]. The codeswitching phenomenon as described above is not only found in oral communication, but also in written communication, especially on social media. In this era of information technology, social media is an important means of communication for society [8]. Social media in cyberspace, such as Twitter, blogs, Instagram, and online discussion forums today are very popular with the world community and are very effective as a medium of communication.

Twitter is one of the popular social media for the Indonesian people. Indonesian people often use Twitter to share information, feelings, etc. Twitter tends to be used for fun and to convey something through writing. Therefore, Twitter is one of the largest social media platforms used by Indonesians to interact in writing form. On Twitter, we often find some users who use more than one language or what we are familiar with as bilingual or use two or more languages. Code switching is divided into three types, namely tag switching, intersentential and intra-sentential [9]. Tag switching is a free element in the language of a question sentence or statement which is located at the beginning or the end of the sentence. Intra-sentential switching occurs within a sentence or a clause '[10]. Intra-sentential code switching is contained in sentences or clauses.

Usually found in the form of a word or phrase. Inter-sentential Switching according to Pop lack "this is the most complex type of code switching because the speaker has to control two linguistic system simultaneously [11]." Inter-sentential switching is the type that is rarely used because it is more complex in the form of clauses and sentences. In connection with this code switching, Chaer and Agustina explain that code switching is the replacement of language or types of language by a speaker in certain circumstances, consciously. There are three types of code switching, namely, tag switching, inter-sentential, and intrasentential. Tag switching is a type classified as a free element contained in a statement or question [9]. Examples of tag switching that are included in discourse markers are 'you know', 'I mean', 'by the way', 'hi', 'okay', etc.

"Intra-sentential switching occurs within a sentence or a clause" [6]. It is mainly found in the form of a word or phrase. According to Pop lack, Inter-sentential Switching is defined, as "this is the most complex type of code switching because the speaker has to control two linguistic systems simultaneously". Inter-sentential switching is a type of code switching that requires flexibility for the speaker to be able to speak in two languages at once in a more complex form, namely in the form of clauses or sentences [7]. Furthermore, several things 
can cause the factors that cause code switching in certain societies. Some of the factors causing the occurrence include speakers, speaking partners, topics, mere prestige and changes in situation [8].

Referring to the explanation above, there is a phenomenon of mixing languages (code switching) between Javanese and Indonesian (Jawanesia), especially on social media. Therefore, through this research, the Jawanesia phenomenon will be discussed and presented on the twitter social media. The results of this study are expected to provide an overview of the development of linguistic phenomena among adolescents, especially those summarized in their social media activities.

\section{Research Method}

This research is a qualitative descriptive study. This study aims to describe various qualitative information with careful descriptions and nuances to describe individually or in groups, events, symptoms or phenomena [9]. This research was conducted on social media networks, namely a social media application Twitter. This Twitter application was chosen because it is widely used by young people and there is a use of code switching in this network which describes linguistic behavior and the attitudes and views of informants in formal and informal situations.

Through purposive sampling technique, the sample of this study was sampled, from the data source in the form of text uploaded on social media. The research data were collected through the observation and note technique. These techniques are the basis for essential data collection in case studies [10]. Furthermore, the data were validated using source triangulation techniques, and analyzed using content analysis techniques by inductive methods with interactive models from Miles \& Huberman which involved three components including data reduction, data presentation, and drawing conclusions/verification [11].

\section{Results and Discussion}

Slang is a language that is often used by a group of people in society. Slang is characterized by Indonesian words or dialect words that are cut off the last two phonemes and then the -ok- form is inserted in front of the last remaining phoneme [12]. Indonesian language has many varieties and variations. This is because the Indonesian language is very widely used and has a wide variety of speakers. The criteria for language variety include: (1) geographic and social background of the speakers, (2) the medium used, and (3) the subject of discussion. The variety of languages concerns all the personal problems of the speakers, such as age, education, gender, occupation, social status, economic status, etc.

Based on age, different language variations are used by children, adolescents, adults, and people classified as elderly. Slang is usually used by teenagers in everyday conversation. Slang is generally used as a means of communication among a group of teenagers during a certain period. This happens because teenagers have their own language in expressing themselves. The linguistic situation in language societies is often complicated because there is more than one language spoken. The complexity is because they have to determine in what language they should communicate with each other. In addition, speakers must also be able to determine which variations of the code are suitable for their situation. Thus, every 
bilingual community must choose the wrong variation of the code used in a speech. As a result of the bilingual situation in the speech community, it shows that there are determining factors in making decisions in a speech.

One of the benefits of this social networking site is that anyone and anywhere, speakers can connect directly with many people as well as can communicate with them in two-way. On Twitter, we often encounter bilingual language users (use of two or more languages). The use of bilinguals is associated with translation and mixing of languages to communicate. The focus of this research is on the use of code switching, code mixing, and determinants of the choice of language code used by language users. The forms of code switching in twitter are grouped into three categories, namely inter-sentential switching, intra-sentential switching, and emblematic switching (symbolic code switching).

The presence of code switching in the form of a word indicates that the word or term that is indeed popular in English, tends to be maintained in English. Words are still used in the English form, because the respondents consider it more appropriate to be expressed in the English form. In addition to appearing in the form of words, in-sentence code switching also appears in the form of: noun phrases, adjective phrases, verb phrases, prepositional phrases, adverb phrases. Noun phrases dominate code switching in Path (one of social medias) status. The transcoded phrase is a phrase that is commonly expressed in English. This shows that the use of names or terms is often more accurately conveyed in English.

\subsection{Inter-sentential Switching}

Code switching between sentences occurs in Indonesian to Javanese and vice versa. In the speech below, code switching between sentences occurs which appears in the form of phrases or clauses. Based on several cases the use of Javanese-Indonesian code switching in a tweet on twitter shows that code switching does not only occur between languages, but can also occur between variations or styles that exist in one language. That is, for example, the change between the casual and the official types of language.

Based on data on social media, Twitter shows symptoms of code switching between sentences. In several data groups (1-a), the use of sentences in Indonesian appears at the beginning. Then, in the last sentence the Javanese sentence suddenly appeared. The use of the expression "Gayeng kagem kulo panjenengan sedoyo" (En: Pleasure for all of us) above shows an effort to respect, refine, as well as prove that everything will be all right. Different things are found in data (1-b). The code-switching form between sentences in data (1-b) has a different function from data (1-a). If the code switching in data tweets (1-a) shows a refinement effort because it uses a fine Javanese form, the code switching in data tweets (1b) shows a symptom of emotional outlet. The Javanese form of Ngoko (lower class language of Javanese) is a sign of the emotional outburst that the writer feels. This emotional expression is more pronounced when expressed in Javanese. Then, as a form of emotional neutralization, Indonesian is used as a closing.

The sentences in the data set indicate the occurrence of the Javanese phenomenon due to the unnatural mixing of Javanese and English words. In sentence (1), there is a form of the word kenawhy, which is a combination of why and why. The two words are combined together to give the impression of using English. Sentence (2) displays the word 'because' which is written in Javanese pronunciation, namely bikos. This phenomenon is also quite prevalent in slang speech among teenagers. This model is identical to the way Malay Malaysians absorb English words. It is just that the Indonesian language has different rules. 


\subsection{Intra-sentential Switching}

Code switching that occurs in one sentence (intra-sentential) is found in the following tweets. Intra-sentential code switching appears in the form of words, phrases, or clauses in one sentence building. Here are two examples of the Javanese-Indonesian code-switching phenomenon in tweets. The tweets in data (2-a) above indicate a symptom of code switching at the word level, namely the use of the word "bledeg" (En: thunder) in place of lightning. The use of the word bledeg gives a hyperbolic impression of the situation at hand. The word bledeg here suggests a picture of an event more terrifying than lightning.

Then, the tweet on data (2-a) also contains an element of code switching in the form of a clause. The clause is a form of direct quotation that is expressed by someone to the author. The use of Javanese clauses is intended to provide a description of the real situation. In addition, many speakers use foreign language code switching in the context that each speaker has a different communication background. Sociolinguistic studies on the phenomenon of switching from a mother tongue to a foreign language are a form of speech at the level of key and norms in linguistic situations. The 3-x data in the metadata shows that the speakers on twitter make utterances that contain code switching in the form of a single sentence.

Single sentences in English are categorized into inter-sentence code switching because all respondents speak Indonesian, so when the respondent uses the language in another code, there is a code change from the mother tongue to the foreign language, in this case, English. The single sentence with code switching occurs in the form of code switching from Indonesian to English. Furthermore, the form of Javanese-Indonesian code switching in the data tweet (2-b) shows a unique phenomenon. This code transfer is in the form of a clause. The use of Javanese elements in this context is more intended to get a more beautiful sound. The form of the clause "tapi lali kuncine neng ndi" (En: But I forget where they key is) has the same rhyme form as the initial clause, which is "pengin buka hati" (En: I want to open your heart).

\subsection{Symbolic Code Switching (Emblematic Switching)}

The use of slang is very fast growing on social networks such as Twitter, Facebook, Instagram, WhatsApp, etc. This is the influence of technological developments, most of the users are teenagers. The language of adolescents or teenagers as one of the variants of the Indonesian language spoken by teenagers in everyday life, in various contexts, shows different forms [13]. The growth of slang in the midst of the Indonesian language cannot be avoided, but can be minimized.

Symbolic code switching occurs because of certain phrases or markings in Indonesian that are inserted into Javanese or vice versa. Following are two data forms of symbolic code switching from Javanese to Indonesian or vice versa. Some of the data on the Twitter social media account is a symbolic code change because there is a change in language from Javanese to Indonesian. This symbolic form is manifested in an attempt to play some difficult words. Meanwhile, in figure (3-b), there is a symbolic code transfer, namely a change from Indonesian to Javanese from the phrase "aku terlalu nyaman" which continues into a phrase in Javanese "akhire nganti lali" then into the phrase in Indonesian again "sebatas teman".

Code mixing is the use of language elements, from one language through special speech into another. Code mixing occurs when a speaker inserts elements of another language while using a particular language. In addition, there is the concept of code mixing which describes code differences as the behavior of two languages in a speech when the lexical elements in the two languages combine into one language structure used in the utterance. In other words, 
coding language is able to emphasize the difference between code mixing from code switching, that is, code mixing behavior appears at the level of words and phrases.

Code mixing on Twitter shows a phenomenon of code or language switching carried out by a speaker in one utterance in a classical and massive manner, so that the thing that becomes the benchmark in the code-mixing process is the lexical form and grammatical system of the language used. The speaker does not change the existing grammar structure, but one tries to maintain the grammar structure by inserting lexical elements from other languages so that the information conveyed through these utterances can be understood properly by others.

In addition, code mixing can also occur because of two things, namely the speaker knows that he and the other speaker have the same language background or the speaker deliberately wants to show that he is accustomed to using two languages in communicating so that code mixing often appears in every speech. The information conveyed through the mass media is massive and two-way with an open response system. The information received can be responded to by the speech partners using different languages; in other words, language.

\section{Conclusions}

People in a technology-based cultural environment demand massive but interactive interaction through social media. The use of Twitter as an open two-way communication tool shows a variety of utterances influenced by the social environment of the speakers. Language speakers must interact with each other or communicate in all forms of social activities. In communicating or interacting, they use a code or language, both written and spoken, that they are familiar with, especially their own mother tongue; otherwise, they cannot carry out any action or process of communication at all. In other words, a communication cannot occur without a language, both verbal and non-verbal language. It can be clearly stated that there is no society that does not use language. It is only in society that a language is applied.

The discussion on code form and code mixing has the aim of knowing the characteristics of the type, form, factor, and impact of using code switching and code mixing. The data collected is then sorted based on the cases of code switching and code mixing contained, then analyzed by descriptive analysis techniques according to the context. Based on the results of the analysis above, the conclusion is that the phenomenon of jawanesia (JavaneseIndonesian code switching) in tweets on Twitter includes three patterns, namely intersentential code switching, intra-sentential code switching, and symbolic code switching or emblematic switching.

The form of code switching in a tweet on Twitter can be in the form of words, phrases or clauses. The use of Javanese-Indonesian code switching has several functions, namely refining, coarsening, upgrading, and transferring. The phenomenon of jawanesia in tweets on social media is a form of language creativity that cannot be avoided, especially for Indonesians who are predominantly bilingual. Therefore, this jawanesia phenomenon must be addressed wisely. In addition, the message to be wise is also conveyed to social media users so that the social media they use does not have a negative impact for life.

\section{References}

[1] P. Trudgill, Sociolinguistics: An Introduction. Great Britain. Hazell Watson \& Viney Ltd., 1974.

[2] N. Hickerson, Linguistik Anthropology. New York: Holt, Rinehart and Winston Inc, 1980. 
[3] E. Sudaryanto, Memet; Sumarwati; Suryanto, "Register Anak Jalanan Kota Surakarta," vol. I, no. April, pp. 514-528, 2014.

[4] G. Williams, "The Ethnography of Communication," in Sociolinguistics, Routledge, 2018, pp. 172-205.

[5] K. Saddhono, "Kajian Sosiolinguistik Pemakaian Bahasa Asing dalam Pembelajaran Bahasa Indonesia untuk Penutur Asing (BIPA)," Kaji. Linguist. dan Sastra, 2012.

[6] Kamaruddin, Kedwibahasaan dan Pendidikan Dwibahasa (pengantar). Jakarta: Depdikbud, 1989.

[7] J. F. Hamers and M. H. A. Blanc, Bilinguality and Bilingualism. Cambridge: Cambridge University Press., 1993.

[8] K. Saddhono, A. Hasibuan, and M. I. Bakhtiar, "Facebook as A Learning Media in TISOL (Teaching Indonesian to Speakers of Other Languages) Learning to Support the Independency of Foreign Students in Indonesia," J. Phys. Conf. Ser., vol. 1, 2019.

[9] S Romaine, Language in society: an introduction to sociolinguistics. London: Longman, 1989.

[10] N Nahdiah, Alih kode penutur L2 bahasa Jepang dalam tweet. Jakarta: Universitas Indonesia., 2012.

[11] Hendar and T.S. Yunita, Penggunaan alih kode dalam program siaransal (Shine after lunch) di radio ardan 105.9 FM Bandung. bandung: Bandung Press, 2012.

[12] R. Kuzar, "Constructions: A construction grammar approach to argument structure," J. Pragmat., 2003.

[13] N. R. Norrick, “Humor in interaction,” Linguist. Lang. Compass, 2010. 